\title{
Exertional hypotension due to postganglionic sympathetic blocking drugs
}

\author{
S. TALBOT \\ M.B., B.S., M.R.C.P. \\ G. W. GILL \\ B.Sc.
}

Sheffield Hypertension Clinic, Royal Infirmary, Sheffield S6 3DA

\begin{abstract}
Summary
Debrisoquine, guanethidine and bethanidine may produce troublesome hypotensive symptoms related to exertion. Thirteen patients with such symptoms were exercised on a treadmill and the response of blood pressure and heart rate was compared to that of thirty patients without these symptoms, who were exercised to the same extent.

There was a slight drop of systolic and diastolic pressures on standing in both groups, but after exertion there was a significantly greater drop of systolic pressure in the group with symptoms than in the asymptomatic group. The diastolic pressure after exertion was significantly lower in the group with symptoms. It was impossible to predict from the standing blood pressure levels at rest which patients would develop hypotensive symptoms after exertion. All three drugs had a similar negative chronotropic effect at rest and on exercise.

It is suggested that patients are exercised during control of hypertension in order to identify those prone to exertional hypotension. Patients with such hypotension should be exercised on each attendance before the blood pressure is measured. Treatment other than postganglionic sympathetic blocking drugs should be employed whenever possible in patients with milder hypertension.
\end{abstract}

\section{Introduction}

Untreated hypertensive patients respond to exercise by a variable rise in the systolic and diastolic pressures. However, if the rise is expressed as a percentage of the basal level, the figures are similar to those of normotensives (Taylor, Donald and Bishop, 1957; Ewing et al., 1973). Occasionally there may be marked vasodilatation and, despite the increase of cardiac output, the blood pressure may fall. The effect of exercise on the blood pressure levels of hypertensive patients treated with hypotensive drugs is variable, but severe hypotension may be produced by upright exertion in patients on guanethidine (Dollery, Emslie-Smith and Milne, 1960; Khatri and Cohn, 1970; Prichard et al., 1968). This can occur

Address for reprints: Dr S. Talbot, Cardiovascular Division, Hammersmith Hospital, Du Cane Road, London. with the other post-ganglionic sympathetic blocking drugs, bethanidine and debrisoquine. Hypotension usually occurs after exertion, but it can occur during exertion and increase after exertion.

Whereas most patients are not affected by symptoms of exertional hypotension, some are severely disabled. It therefore appeared important to identify these patients preferably before exertion. Exercise in the upright position has not been standardized satisfactorily by Master's two-step test, since this test is affected by the effort of the patient. Treadmill exercise more closely resembles normal walking and has been used in the assessment of coronary artery disease (Bruce, Kusumi and Hosmer, 1973). It was therefore used to assess the hypertensives' response to exercise before and after treatment. Because both reduction of cardiac output and diminished peripheral resistance may contribute to exertional hypotension, it was decided to evaluate the negative chronotropic and hypotensive effects of postganglionic sympathetic blocking drugs.

\section{Patients and method}

During a 2-year period, patients followed-up at the Sheffield Hypertension Clinic who were receiving treatment with guanethidine, debrisoquine or bethanidine were asked about symptoms that could be related to posture and exertion. After dosage adjustments, some patients still complained of persistent dizziness on upright exertion but did not have significant orthostatic hypotension in the clinic. If they agreed to further investigation they were submitted to a standard treadmill test. This was preceded by a 12-lead electrocardiogram, chest radiograph and blood urea and electrolytes. All the patients were male and had essential hypertension without angina pectoris, cardiac failure, papilloedema or any significant disability. There were twenty-two patients in this group.

Exercise consisted of $3 \mathrm{~min}$ with the treadmill horizontal, then $5 \mathrm{~min}$ at $5^{\circ}$ and finally $5 \mathrm{~min}$ at $10^{\circ}$, all at a rate of 2 m.p.h. The length of the exercise was determined by experience; longer periods of exercise were often not tolerated either before or after treatment. Even so, the 1est as outlined above 
had to be stopped in six patients because of hypotensive symptoms after treatment. If possible the dose of drug was reduced and the test was repeated later. The blood pressure was measured by a sphygmomanometer to the nearest $2 \mathrm{mmHg}$ at rest, supine and erect, during exertion at the end of the three exercise periods, within $1 \mathrm{~min}$ after exercise and then immediately following this in the supine position. The heart rate was measured throughout exercise by an electrocardiographic recording. Satisfactory $\beta$-blockade was confirmed by Valsalva's manoeuvre (Sandler, Leishman and Humberstone, 1968; Jacono et al., 1967).

The responses of the blood pressure and heart rate of these patients to exercise were compared with a group of thirty treated patients, who did not complain of postural symptoms during or after exertion. Twenty-five of these patients were exercised to a similar degree before treatment. The standard exercise was performed when the standing blood pressure was adequately controlled, and it was preceded by the same routine investigations and by the same precautions as in the group with symptoms.

\section{Results}

Sixteen of twenty-two patients with suggestive symptoms of exertional hypotension developed such symptoms during or after exercise associated with a drop of at least $10 \mathrm{mmHg}$ in the systolic pressure in the erect position. Six of these had to stop exercise prematurely, because of hypotension during exercise, but a subsequent exercise was completed for three of them when they were receiving a reduced dose of their hypotensive drug. All three developed hypotensive symptoms after exercise, and the results were therefore amalgamated with the ten patients who only developed hypotensive symptoms after exertion. The remaining six patients did not develop either symptoms or hypotension after exertion and have been excluded from further analysis.

The results of the thirteen patients are presented in Table 1 . Before exertion there was usually a slight drop of the systolic pressure and a smaller drop of diastolic pressure on standing. After exertion there was a marked drop in the systolic pressure and a smaller fall of the diastolic pressure. Blood pressure levels measured during exercise have not been presented but they were never lower than the blood pressure levels after exercise.

Comparable results of the thirty asymptomatic treated patients are presented in Table 2 . There were seven patients on bethanidine, eight on guanethidine and fifteen on debrisoquine. Although systolic pressures were different, diastolic pressures were comparable in the three drug groups. The standing blood pressure levels of the asymptomatic patients before and after treatment were similar to the figures for the group with symptoms. After treatment the changes of both systolic and diastolic pressures on standing from the supine position were similar and significant $(P<0.02)$. However, as expected, the systolic and diastolic pressures dropped more in the erect position after exercise in the group with hypotensive symptoms than in the group without (systolic pressure change, $t=5.0, P<0.01$; diastolic pressure change, $t=4.5, P<0.01)$. The negative chrono-? tropic effect of postganglionic sympathetic blocking drugs was not significantly less in the group with exertional hypotensive symptoms, despite the greater drop of the systolic and diastolic pressures.

It was possible to measure the negative chronotropic effect of postganglionic sympathetic blocking

TABLE 1. The response of symptomatic patients to exercise (s.d. in parentheses)

\begin{tabular}{|c|c|c|c|c|c|}
\hline \multirow[b]{2}{*}{ Therapy } & \multirow[b]{2}{*}{$\begin{array}{l}\text { Standing } \\
\text { pressure } \\
(\mathrm{mmHg})\end{array}$} & \multicolumn{2}{|c|}{ At rest } & \multicolumn{2}{|c|}{ On exercise } \\
\hline & & $\begin{array}{l}\text { Change of systolic } \\
\text { pressure on } \\
\text { standing }(\mathrm{mmHg})\end{array}$ & $\begin{array}{c}\text { Change of diastolic } \\
\text { pressure on } \\
\text { standing }(\mathrm{mmHg})\end{array}$ & $\begin{array}{l}\text { Change of systolic } \\
\text { pressure (erect) } \\
(\mathrm{mmHg})\end{array}$ & $\begin{array}{c}\text { Change of diastolic } \\
\text { pressure (erect) } \\
(\mathrm{mmHg})\end{array}$ \\
\hline Debrisoquine & $200 / 110$ & 0 & 0 & -70 & -20 \\
\hline Debrisoquine & $160 / 110$ & -20 & -10 & -45 & -30 \\
\hline Debrisoquine & $180 / 120$ & -25 & +4 & -55 & -54 \\
\hline Debrisoquine & $170 / 102$ & -16 & -2 & -24 & -16 \\
\hline Debrisoquine & $185 / 108$ & -38 & -10 & -54 & -30 \\
\hline Debrisoquine & $160 / 100$ & +10 & 0 & -70 & -20 \\
\hline Bethanidine & $170 / 95$ & +5 & +7 & -65 & -17 \\
\hline Bethanidine & $190 / 112$ & -40 & -6 & -38 & -32 \\
\hline Bethanidine & $160 / 105$ & +20 & -5 & -100 & -40 \\
\hline Bethanidine & $165 / 90$ & -45 & -20 & -20 & -10 \\
\hline Guanethidine & $150 / 90$ & -10 & -20 & -10 & -5 \\
\hline Guanethidine & $170 / 96$ & -20 & -5 & -20 & -5 \\
\hline Guanethidine & $160 / 90$ & -40 & -15 & -60 & -30 \\
\hline \multicolumn{2}{|c|}{ Mean drop of pressure } & $\begin{array}{c}-16 \cdot 8 \\
(21 \cdot 0)\end{array}$ & $\begin{array}{r}-6 \cdot 3 \\
(8 \cdot 5)\end{array}$ & $\begin{array}{c}-49.4 \\
(24 \cdot 8)\end{array}$ & $\begin{array}{l}-23 \cdot 8 \\
(14 \cdot 1)\end{array}$ \\
\hline
\end{tabular}


TABLE 2. The response of asymptomatic patients to exercise (s.d. in parentheses)

\begin{tabular}{|c|c|c|c|c|c|}
\hline \multirow[b]{2}{*}{ Drug group } & \multirow[b]{2}{*}{$\begin{array}{l}\text { Standing pressure } \\
\text { (before treatment) } \\
\text { (mean mmHg) }\end{array}$} & \multicolumn{2}{|c|}{ At rest } & \multicolumn{2}{|c|}{ On exercise } \\
\hline & & $\begin{array}{l}\text { Systolic pressure } \\
\text { change on standing } \\
\text { (mean } \mathrm{mmHg} \text { ) }\end{array}$ & $\begin{array}{l}\text { Diastolic pressure } \\
\text { change on standing } \\
\text { (mean } \mathrm{mmHg} \text { ) }\end{array}$ & $\begin{array}{l}\text { Systolic pressure } \\
\text { change (erect) } \\
\text { (mean mmHg) }\end{array}$ & $\begin{array}{l}\text { Diastolic pressure } \\
\text { change (erect) } \\
\text { (mean mmHg) }\end{array}$ \\
\hline $\begin{array}{l}\text { Debrisoquine } \\
15 \text { patients }\end{array}$ & $\frac{188 \cdot 3}{121 \cdot 1}$ & $\begin{array}{l}-18 \cdot 0 \\
(27 \cdot 6)\end{array}$ & $\begin{array}{l}-4 \cdot 0 \\
(10 \cdot 1)\end{array}$ & $\begin{array}{c}-13 \cdot 9 \\
(18 \cdot 2)\end{array}$ & $\begin{array}{l}-6 \cdot 1 \\
(10 \cdot 5)\end{array}$ \\
\hline $\begin{array}{l}\text { Bethanidine } \\
7 \text { patients }\end{array}$ & $\frac{193 \cdot 3}{110 \cdot 8}$ & $\begin{array}{l}-16 \cdot 0 \\
(21 \cdot 6)\end{array}$ & $\begin{array}{l}-6 \cdot 0 \\
(11 \cdot 0)\end{array}$ & $\begin{array}{l}-13 \cdot 8 \\
(20 \cdot 2)\end{array}$ & $\begin{array}{c}-9.1 \\
(9 \cdot 5)\end{array}$ \\
\hline $\begin{array}{l}\text { Guanethidine } \\
8 \text { patients }\end{array}$ & $\frac{207 \cdot 0}{124 \cdot 0}$ & $\begin{array}{l}-13 \cdot 0 \\
(24 \cdot 2)\end{array}$ & $\begin{array}{l}-7.5 \\
(11 \cdot 8)\end{array}$ & $\begin{array}{l}-15.6 \\
(21 \cdot 6)\end{array}$ & $\begin{array}{c}-8 \cdot 4 \\
(8 \cdot 9)\end{array}$ \\
\hline Total mean & & $\begin{array}{c}-16 \cdot 2 \\
(25 \cdot 4)\end{array}$ & $\begin{array}{l}-5 \cdot 4 \\
(10 \cdot 8)\end{array}$ & $\begin{array}{c}-14 \cdot 3 \\
(19 \cdot 6)\end{array}$ & $\begin{array}{c}-7 \cdot 6 \\
(9 \cdot 9)\end{array}$ \\
\hline
\end{tabular}

TABLE 3. Heart rates and erect pressures in hypertensive patients without hypotensive symptoms

\begin{tabular}{|c|c|c|c|c|c|}
\hline Group & & $\begin{array}{c}\text { Blood pressure } \\
\text { (mmHg) before } \\
\text { treatment }\end{array}$ & $\begin{array}{c}\text { Blood pressure } \\
\text { (mmHg) after } \\
\text { treatment }\end{array}$ & $\begin{array}{l}\text { Heart rate } \\
\text { before } \\
\text { treatment }\end{array}$ & $\begin{array}{l}\text { Heart rate } \\
\text { after } \\
\text { treatment }\end{array}$ \\
\hline $\begin{array}{l}\text { Group 1 } \\
\text { Bethanidine } \\
\text { (5 patients) }\end{array}$ & $\begin{array}{c}\text { At rest/ } \\
\text { On exercise }\end{array}$ & $\begin{array}{l}193 \cdot 8 / 121 \cdot 4 \\
198 \cdot 8 / 119 \cdot 6\end{array}$ & $\begin{array}{l}170 \cdot 0 / 101 \cdot 4 \\
157 \cdot 5 / 96 \cdot 4\end{array}$ & $\begin{array}{c}98 \cdot 5 * \\
135 \cdot 3 \dagger\end{array}$ & $\begin{array}{r}74^{*}(-24 \cdot 9) \\
103 \dagger(-23 \cdot 8)\end{array}$ \\
\hline $\begin{array}{l}\text { Group } 2 \\
\text { Debrisoquine } \\
\text { (14 patients) }\end{array}$ & $\begin{array}{c}\text { At rest/ } \\
\text { On exercise }\end{array}$ & $\begin{array}{l}178 \cdot 3 / 121 \cdot 1 \\
203 \cdot 3 / 130 \cdot 0\end{array}$ & $\begin{array}{l}158 \cdot 3 / 96 \cdot 7 \\
150 \cdot 0 / 100 \cdot 0\end{array}$ & $\begin{array}{r}81 \cdot 3^{*} \\
130 \cdot 7 \dagger\end{array}$ & $\begin{array}{l}60 \cdot 0 *(-24) \\
99 \cdot 3 \dagger(-26 \cdot 2)\end{array}$ \\
\hline $\begin{array}{l}\text { Group } 3 \\
\text { (6 patients) }\end{array}$ & $\begin{array}{c}\text { At rest/ } \\
\text { On exercise }\end{array}$ & $\begin{array}{l}207 \cdot 0 / 124 \cdot 0 \\
220 \cdot 0 / 125 \cdot 0\end{array}$ & $\begin{array}{l}166 \cdot 7 / 96 \cdot 7 \\
140.0 / 83.3\end{array}$ & $\begin{array}{l}102 \cdot 7^{*} \\
128 \cdot 7 \dagger\end{array}$ & $\begin{array}{l}64 \cdot 7^{*}(-37 \cdot 0) \\
93 \cdot 3 \dagger(-27 \cdot 5)\end{array}$ \\
\hline
\end{tabular}

* Significant differences at rest $(t=3.6, P<0.01)$.

$\dagger$ Significant differences on exercise $(t=4.9, P<0.01)$.

TABLE 4. Predictors of exertional hypotension with symptoms ( $\%$ in parentheses)

\begin{tabular}{lcc}
\hline & Exertional hypotension & No exertional hypotension \\
\hline $\begin{array}{l}\text { Number of patients } \\
\begin{array}{l}\text { Electrocardiographic } \\
\text { evidence of left ventricular }\end{array}\end{array}$ & 13 & 30 \\
$\begin{array}{l}\text { hypertrophy } \\
\text { ST } / \text { T wave changes } \\
\text { on electrocardiogram }\end{array}$ & $10(77)$ & $11(37)$ \\
$\begin{array}{l}\text { Cardiomegaly } \\
\text { Blood urea }>40 \mathrm{mg} / 100 \mathrm{ml}\end{array}$ & $7(54)$ & $10(33)$ \\
\hline
\end{tabular}

drugs in the patients who were exercised both before and after treatment. The results are described in Table 3. The three drugs had comparable negative chronotropic effects both at rest and on exercise. Debrisoquine reduced the heart rate by $25 \%$, bethanidine by $24 \%$ and guanethidine by $32 \%$ (Table 3 ).

The simple investigations which have been found to be useful predictors of symptoms due to postural hypotension both on standing and on exercise (Talbot and Smith, 1975) are presented in Table 4. The blood urea was more frequently abnormal and cardiomegaly was more frequently found by chest radiograph in the group with hypotensive symptoms. ST/T wave changes on the electrocardiogram were more frequent as were voltage criteria of left ventricular hypertrophy (Sokolow and Lyon, 1949). However, the number of patients was small and these results were not significant.

Symptoms related to hypotension either during or after exercise may be very troublesome in everyday life. It has been observed that reduction of the dose of postganglionic sympathetic blocking drug often reduces the symptoms but there is still usually a drop of pressure on or after exertion despite high 
blood pressure at rest. Because of this, it is usually necessary to add a drug without an $\alpha$-adrenergic blocking action and the authors have found $\alpha$ methyldopa the most useful.

\section{Discussion}

The haemodynamic responses of hypertensive patients after treatment have not been as well evaluated as before treatment. Exercise has a variable effect on the peripheral resistance before treatment and, since the cardiac output rises, the response of the blood pressure is also variable although there is usually a rise of systolic and diastolic pressures. The response may vary depending on whether the exercise is static or dynamic. (Taylor et al., 1957; Hoel, Lorentsen and Lund-Larsen, 1970; Ewing et al., 1973; Sonnerstedt, 1966).

Postganglionic sympathetic blocking drugs produce their principal hypotensive effect on standing because there is reduced compensation for the drop in cardiac output due to venous pooling. The block of peripheral vasoconstriction can also be demonstrated by Valsalva's manoeuvre. The postural hypotension is a cause of troublesome side effects. However, some patients find that hypotensive symptoms occur predominantly on or after exercise.

This study has shown that exercise has a variable effect on the blood pressure of asymptomatic, treated patients. Usually there is a small drop in the systolic and diastolic pressures. However, patients with symptoms of exertional hypotension develop a significantly greater drop of these pressures after exercise. Occasionally the pressure may drop enough during exertion for hypotensive symptoms to develop. The symptomatic patients have similar drops in systolic and diastolic pressures on standing to those of asymptomatic patients.

It must be stressed that it was impossible to forecast from the response of the blood pressure to standing from the supine position what the response would be to exercise.

It was not considered justifiable to exercise patients who complained of postural symptoms on standing up or who were severely disabled by the cardiovascular complications of hypertension. The select group that were exercised may therefore either have an unusual response to exercise (which may have been present before treatment) or a degree of postganglionic sympathetic blockade which can only be demonstrated after the stress of exercise.

Hypotension after exertion is due to the drop in cardiac output due to venous pooling and inadequate peripheral resistance. If it occurs during exertion it must be due to cardiac insufficiency or inadequate peripheral resistance or both. After treatment with postganglionic sympathetic blocking drugs, the hypotensive response to exercise is usually mild. The few patients who have hypotensive symptoms could have excessive peripheral vasodilatation. However, any negative inotropic or chronotropic effect of these drugs might accentuate this effect.

The inotropic effects of these drugs appear to be minimal. Acute administration of guanethidine has a positive inotropic effect probably due to release of catecholamines, but a negative inotropic effect after physiological denervation (Kahler, Gaffney and Braunwald, 1962). Later, in animals and possibly in man, denervation and treatment with guanethidine increases the sensitivity of the heart to catecholamines, and positive inotropism may occur. Debrisoquine causes a slight reduction of cardiac output in the supine position (Onesti et al., 1966). Bethanidine may have a similar effect since both drugs do not appear to deplete tissues of catecholamines. However, the long-term effects of these drugs on cardiac function are unknown.

The negative chronotropic effects of these drugappear to be similar on exercise although guanethis dine appears the most potent at rest. Other studies on the effects of debrisoquine and guanethidine on supine exercise have produced similar results (Moe et al., 1964; Gaffney, Braunwald and Cooper, 1962; Vernikos-Danellis and Zaimis, 1960) but there is little information on bethanidine. The intrinsic heart rate is not affected by guanethidine, debrisoquine or $\alpha$-methyldopa (Kaldor and Juvancz, 1969). It is likely that the postganglionic sympathetic blocking drugs exert their maximum effect on the heart rate by a $\beta$-blocking effect, since atropine does not influence the response, although depletion of catecholamines by guanethidine may increase the effect of this drug on the resting heart rate.

The negative chronotropic effect may potentiate cardiac failure. Hypotension in the erect patient with cardiac insufficiency may also be potentiated by such an effect. The postural hypotension that may develop in hypertensive patients, who sustain a myocardial infarction or an arrhythmia, highlights the importance of the cardiac output as well as the peripheral resistance. The association of electrocardiographic abnormalities and cardiomegaly with postural hypotensive symptoms at rest (Talbot and Smith, 1975) and after exercise supports this suggestion.

It is proposed that some patients are more prone to postural hypotension than others. Exercise accentuates this hypotension and in some patients may be the only time that significant hypotension and symptoms occur. Since it is not possible to identify these patients without exercise, it is important that all patients who are well controlled at rest should be exercised at the time of maximum drug effect. This should be done early in the course of treatment. If hypotension occurs, exercise should 
be performed at each out-patient attendance. If not, it would appear to be unnecessary. Climbing stairs produces a similar response of blood pressure to that of the treadmill test and would seem to be a suitable alternative.

However, the supervision and continuous electrocardiographic monitoring of a standard treadmill exercise is valuable, and may yield additional information. In particular, it is important to confirm that dizziness on exertion is due to hypotension, since it may be due to other factors requiring different treatment. In the presence of significant exertional hypotension, the authors recommend either combination therapy or therapy without $\alpha$-sympathetic blocking effect.

\section{Acknowledgments}

We are grateful for the advice of Dr A. J. Smith and the staff of the Sheffield Hypertension Clinic.

\section{References}

Bruce, R.A., Kusumi, F. \& Hosmer, D. (1973) Maximal oxygen intake and nomographic assessment of functional aerobic impairment in cardiovascular disease. American Heart Journal, 85, 546.

Dollery, C.T., EmSlie-Smith, D. \& Milne, M.D. (1960) Clinical and pharmacological studies with guanethidine in the treatment of hypertension. Lancet, ii, 381 .

Ewing, D.J., Irving, J.B., KerR, F. \& KIRBY, B.J. (1973) Static exercises in untreated systemic hypertension. British Heart Journal, 35, 413.

GaffNey, T.E., Braunwald, E. \& Cooper, T. (1962) Analysis of the acute circulatory effects of guanethidine and Bredyllium. Circulation Research, 10, 83.

Hoel, B.L., Lorentsen, E. \& Lund-LARSEN, P.G. (1970) Haemodynamic responses to sustained handgrip in patients with hypertension. Acta medica scandinavica, 188, 491.
Jacono, A., Vitali, P., Divitus, O. de \& Perna, N. (1967) The assessment by means of Valsalva's manoeuvre of the haemodynamic changes caused by blockade of the receptors. Cuore e Circolazione, 51, 3, 129.

Kahler, R.L., GaffNey, T.E. \& Braunwald, E. (1962) The effects of automatic nervous system inhibition on the circulatory response to muscular exercise. Journal of Clinical Investigation, 41, 1981.

KAldoR, A. \& JuVANCZ, P. (1969) Effect of antihypertensive drugs on the intrinsic heart rate. British Medical Journal, 2, 486.

KHATRI, I.M. \& CoHN, J.N. (1970) Mechanism of exercise hypotension after sympathetic blockade. American Journal of Cardiology, 25, 329.

Moe, R.A., Bates, H.M., Palkoski, Z.M. \& Danziger, R. (1964) Cardiovascular effects of 3, 4-dihydro-2 (I.H.) isoquinoline carboamidine (Declinax). Current Therapeutic Research, 6, 299.

Onesti, G., LA Schiazza, D., Brest, A.N. \& Moyer, J.H. (1966) Cardiac and renal hemodynamic effects of debrisoquine sulphate in hypertensive patients. Clinical Pharmacology and Therapeutics, 7, 17.

Prichard, B.N.C., Johnston, A.W., Hill, I.D. \& RosenHEIM, M.L. (1968) Guanethidine and methyldopa in treatment of hypertension, a within-patient comparison. British Medical Journal, 1, 135.

Sandler, G., Leishman, A.W.D. \& Humberstone, P.M. (1968) Guanethidine-resistant hypertension. Circulation, $38,542$.

SoKolow, M. \& LYON, T.P. (1949) The ventricular complex in left ventricular hypertrophy as obtained by unipolar precordial and limb leads. American Heart Journal, 37, 161.

SONNERSTEDT, T.R. (1966) Haemodynamic response to exercise in patients with arterial hypertension. Acta medica scandinavica, 458 (Suppl.), 55.

TALbot, S. \& SMITH, A.J. (1975) Factors predisposing to postural hypotensive symptoms in the treatment of high blood pressure. British Heart Journal, 37, 1059.

TAYlOR, S.H., Donald, K.W. \& Bishop, J.M. (1957) Circulatory studies in hypertensive patients at rest and during exercise. Clinical Science, 16, 351.

Vernikos-Danellis, J.V. \& Zaimis, E. (1960) Some pharmacological actions of Bretyllium and guanethidine. Lancet, ii, 787. 